\title{
PERANAN HUKUM ADAT MASYARAKAT DAYAK DALAM MENYELESAIKAN KONFLIK UNTUK MEWUJUDKAN KEADILAN DAN KEDAMAIAN
}

\author{
(The Role of the Dayak Customary Law in Resolving Conflict to Realize Justice and Peace)
}

\author{
Yuliyanto \\ Pusat Penelitian dan Pengembangan Hukum \\ Badan Penelitian dan Pengembangan Hukum dan HAM \\ Jalan H.R. Rasuna Said Kavling 4-5 Kuningan, Jakarta Selatan \\ Email: yuliyanto_oke@yahoo.com
}

Naskah diterima: 20 Maret 2017; revisi: 13 April 2017; disetujui: 17 April 2017

\begin{abstract}
Abstrak
Dua fenomena politik dan sosial utama yang muncul pada masa setelah Orde Baru adalah konflik, dan kembalinya identitas adat (revitalisasi adat) di daerah-daerah. Tidak hanya sekedar menjadi jargon belaka, namun di beberapa tempat, upaya revitalisasi kelembagaan adat termasuk peran sosialnya didukung oleh berbagai pihak. Dalam konteks setelah Orde Baru, dengan fasilitasi otonomi daerah dan berlakunya desentralisasi, maka keinginan untuk memberlakukan kembali kearifan tradisional atau kerap disebut dengan "mekanisme adat" untuk mewujudkan keadilan dan kedamaian mulai berkembang. Berawal dari pemahaman tersebut maka diperlukan sebuah penelitian yang mampu membahas suatu permasalahan: makna dan cakupan pranata adat di Kalimantan Tengah; bagaimana posisi, peran dan pengaruh pranata adat terutama dalam pencegahan dan penghentian konflik di masyarakat; bagaimana relevansi pranata adat dikaitkan dengan UndangUndang Nomor 7 tahun 2012. Metode penelitian yang digunakan adalah penelitian yuridis sosiologis, artinya suatu penelitian yang dilakukan terhadap keadaan nyata masyarakat atau lingkungan masyarakat dengan maksud dan tujuan untuk menemukan fakta yang kemudian menuju pada identifikasi dan pada akhirnya menuju kepada penyelesaian masalah. Teknik pengumpulan data yang digunakan adalah studi dokumen dan penelitian lapangan dengan melakukan wawancara. Hasil dari penelitian ini memberikan rekomendasi kepada Pemerintah daerah harus melibatkan pranata adat dan tokoh adat setempat dalam penanganan konflik sosial yang terjadi di daerahnya; untuk Pemerintah Pusat dalam hal ini Direktorat Jenderal Peraturan Perundang-Undangan perlu menerbitkan Peraturan Pemerintah Pelaksanaan Undang-Undang Nomor 7 Tahun 2012 tentang Penanganan Konflik Sosial yang di dalamnya memuat secara komprehensif pelibatan pranata adat dan tokoh adat dalam penanganan konflik sosial.
\end{abstract}

Kata Kunci: hukum adat, masyarakat Dayak, konflik sosial

\begin{abstract}
Two major political and social phenomena that emerged in the aftermath of the New Order is conflict, and the return of indigenous identity (cultural revitalization) in the regions. Not just be a mere jargon, in some places, efforts to revitalize traditional institutions including social roles supported by various parties. In the context after the New Order, by the facilitation of regional autonomy and decentralization, the desire to reinstate the traditional wisdom often called the " traditional mechanism "to bring about justice and peace began to flourish.From that understanding, there is need to discuss and research on the meaning and scope of traditions in Central Kalimantan; how the position, role and influence of traditions, especially in the prevention and cessation of conflict in society; how the relevance of traditions associated with Law Nomor 7 of 2012. The method used is the juridical sociological research, meaning a study of the real state of society or community environment with the intent and purpose of finding facts which then leads to the identification and ultimately lead to the settlement of the problem. The data collection technique used is the study of documents and field research by conducting interviews. The results of this study provide recommendations to the local government institutions to involve indigenous and local traditional leaders in conflict resolution happens in their areas; The Central Government, in this context, the Directorate-General of Regulation needs to issue Government Regulation Act Nomor 7 of 2012 on Social Conflict Management in which includes a comprehensive engagement of traditions and traditional leaders in handling social conflicts.
\end{abstract}

Keywords: customary law, the Dayak community, social conflict 


\section{A. Pendahuluan}

Indonesia merupakan negara dengan karakter sosial dan ekonomi yang heterogen. Kehadiran Indonesia sebagai sebuah negarabangsa merupakan sebuah fenomena unik, terutama jika dilihat dari sisi kemajemukan yang dimilikinya. Tidak saja karena demikian beragam etnis, bahasa dan keyakinan, namun pula dalam hal adaptasi ekonomi, bentuk-bentuk komunitas, sistem politik tradisional, maupun sistem kekerabatan menjadikan keindonesiaan sebagai gejala politik identitas yang menarik. ${ }^{1}$ Dalam situasi tersebut dua tantangan segera hadir manakala bangsa Indonesia itu berdiri, yakni bagaimana menciptakan negara yang mampu merekat kemajemukan di satu sisi dan di sisi lain, mampu mengakomodir kemajukan tersebut hingga tahap yang harmonis namun dinamis. Nasionalisme keindonesiaan yang tegak dan berkiprah di atas prinsip-prinsip solidaritas, inklusivisme, keadaban, kesalingpercayaan dan keberagaman. ${ }^{2}$

Seiring dengan pengunduran diri Presiden Soeharto pada bulan Mei 1998, situasi politik, ekonomi, sosial dan budaya di Indonesia menjadi lebih terbuka dan dinamis. Perubahan cepat terjadi dalam banyak hal terutama perubahan sistem nilai, partisipasi warga dan keterbukaan informasi. Zaman sesudah
Soeharto atau setelah Orde Baru ini dikenal dengan sebutan masa reformasi. ${ }^{3} \mathrm{Di}$ masa Orde Baru, dengan dukungan mutlak aparatur ideologis kekuatan penataran Pembinaan Penghayatan dan Pengamalan Pancasila dan operasi teritorial, pemerintah relatif mampu meredam upaya disintegrasi sosial atau konflik komunal atas dasar keetnisan. Seiring dengan upaya pembangunan ekonomi dan modernisasi politik yang kemudian ditafsirkan menjadi deideologisasi dan penyeragaman segenap aspek kehidupan, persoalan yang bersifat partikular termasuk kekhasan etnis dan pranata adat seolah mengalami sebuah era kegelapan.

Pemerintah cenderung dengan tegas menanggapi segenap pandangan dan kegiatan yang dianggap berpotensi melawan penyeragaman "makna kebangsaan" versi pemerintah. Dalam situasi sedemikian, upaya pengedepanan sentimen etnisitas pun relatif meredup. Apalagi jika dilihat secara umum, Orde Baru mampu melakukan sebuah rekonstruksi sosial dan politik serta perbaikan kehidupan yang dalam batas-batas tertentu mampu meredam kekecewaan dan potensi ledakan kekuatan etnis.

Namun, hal itu tidak menyebabkan persoalan etnisitas ini hilang. Pada masa Orde Baru pemicu utama etnisitas bukan lagi sentimen ideologis atau persoalan politik,

Lihat lebih jauh karya-karya Clifford Geertz. Available Light: Anthropological Reflections on Philosophical Topics (New Jersey: Princeton University Press, 2000); Anderson, Benedict. Imagined Communites: Reflecitions on the Origin and Spread of nationalism (London: Verso, 1983), Hildreed Geertz, "Indonesian Cultures and Communities" dalam Ruth McVey (ed), "Indonesia", Cornell, 1967, hlm.24, dalam Max Lane, Bangsa Yang belum Selesai: Indonesia Sebelum dan Sesudah Soeharto, (Jakarta: Reform Institute, 2007), hlm.1.

2 Lihat Mochtar Pabottinggi, Lima Palang Demokrasi, satu Solusi. Orasi Ilmiah Pengukuhan sebagai Ahli Peneliti Utama, Jakarta: PPW-LIPI, Jakarta 22 Juni 2000.

3 Produk politik di masa ini ditandai dengan berlangsungnya desentralisasi setelah terbitnya UU Otonomi Daerah nomor 22 Tahun 1999 di masa pemerintahan Presiden BJ Habibie, yang diperbarui dengan UU No. 32 Tahun 2004. Desentralisasi ini, yang menekankan pada devolusi wewenang administrasi dan finansial di satu sisi membawa perubahan praktik politik dan khususnya harapan agar kesejahteraan semakin "mendekat" kepada rakyat. 
seperti pengisian jabatan publik yang tidak proporsional, ${ }^{4}$ melainkan masalah ketimpangan ekonomi dan eksploitasi Sumber Daya Alam (SDA). Kedua hal tersebut kerap menjadi pemicu bagi munculnya kesadaran suatu kelompok etnis sebagai korban (victims) dari pihak mayoritas atau "pusat". Hal ini sayangnya kemudian diikuti oleh upaya penyeragamaan dan hegemonisasi budaya semua suku bangsa yang menyebabkan kemudian tersingkirnya jati diri etnis yang khas. Situasi ini juga diperumit dengan dikembangkannya cara-cara otoriter dan represif serta pola pemerintahan terpusat, sehingga tidak saja secara khusus menimbulkan pengkristalan rasa keetnisan - bahkan dalam batas-batas tertentu memunculkan "dendam kolektif" - namun pula secara umum menyebabkan proses pembangunan sebuah kesatuan bangsa dalam lingkup nasional mengalami situasi distorsi berkepanjangan.

Dua fenomena politik dan sosial utama yang muncul pada masa setelah Orde Baru adalah konflik, dan kembalinya identitas adat (revitalisasi adat) di daerah-daerah, keduanya terletak dalam konteks desentralisasi atau otonomi daerah. Tidak hanya sekedar menjadi jargon belaka, namun di beberapa tempat, upaya revitalisasi kelembagaan adat termasuk peran sosialnya didukung oleh berbagai pihak, antara lain organisasi Aliansi Masyarakat Adat Nusantara (AMAN). Di sisi lain ada pula kelompok-kelompok adat yang tidak tergabung dalam AMAN namun mengatasnamakan adat bertindak atas nama kelompok masyarakat, mengklaim kejayaan masa lalu melalui warisan atau praktik kultural mereka.
Dalam konteks setelah Orde Baru, dengan fasilitasi otonomi daerah dan berlakunya desentralisasi, maka keinginan untuk memberlakukan kembali kearifan tradisional atau kerap disebut dengan "mekanisme adat" mulai berkembang. Selain melatarbelakangi munculnya gelombang tuntutan revitalisasi identitas lokal termasuk aspek adat, situasi politik pasca Orde Baru yang transisional itu hingga tinggi di beberapa wilayah. Konflikkonflik dengan berbagai dimensi muncul dalam kondisi lingkungan kelembagaan politik pusat maupun daerah yang lemah, di mana-mana terjadi peralihan kepemilikan kekuasaan dan sumber daya, serta di saat yang sama muncul tantangan terhadap kepentingan-kepentingan strategis yang awalnya eksklusif, baik di ranah kekuasaan pusat maupun di daerah.

Kita telusuri sejenak peristiwa kerusuhan dan konflik-konflik komunal pasca Orde Baru. Diawali oleh konflik bernuansa agama di Poso, Sulawesi Tengah (meletus dua kali tahun 19982001), kerusuhan di Solo dan Jakarta bulan Mei 1999, konflik berdarah berbasiskan isu religius kemudian muncul di Maluku dan Maluku Utara yang berlangsung tiga tahun (1999-2002), lalu konflik komunal berwarna identitas etnis di Sambas, Kalimantan Barat (1997, 1999-2001) dan di Sampit, Kalimantan Tengah (2001). Selain konflik-konflik komunal tersebut, Indonesia pasca Orde Baru juga dihadapkan pada potensi konflik yang besar dari politik represif masa lalu; keinginan merdeka dari Aceh yang diselesaikan melalui perundingan damai Helsinki Tahun 2005; konflik di Timor-Timur-yang kemudian diikuti oleh referendum pada tahun 1999; dan yang masih berlangsung konflik di Papua.

\footnotetext{
4 Menurut Burhan D. Magenda hal-hal itu sejatinya relatif telah tertutupi oleh Orde Baru, lihat Burhan D. Magenda, "Perubahan dan Kesinambungan dalam Pembelahan Masyarakat Indonesia", dalam Prisma, 4, (1990).
} 
Dampak dari konflik-konflik komunal yang berlangsung dalam waktu beberapa tahun itu sangat merugikan masyarakat. Korban jiwa, harta benda, kemiskinan di daerah pengungsian, kesehatan, bersatu-padu. Konflik-konflik komunal itu telah mengambil korban jiwa sebesar 1,3 juta orang termasuk perempuan dan anak-anak. 6 Riset yang dilakukan oleh Bank Dunia (2009) memperlihatkan, dalam konteks Indonesia pasca Soeharto, di satu sisi, ada keterkaitan antara fenomena di permukaan yaitu konflik yang muncul, dengan peristiwa-peristiwa yang mendahului atau melatarbelakangi, sebagai konteks konflik. Sebagian konflik yang terjadi tidak meluas atau berskala besar, namun sebagian konflikkonflik meluas daerah cakupannya sehingga menimbulkan korban jiwa.

Lalu, bagaimana dengan mekanisme penyelesaian konflik yang ada sejauh ini? Melihat pengalaman konflik-konflik komunal dan pola penyelesaiannya, institusi pemerintah dapat dikatakan telah mempunyai pola untuk menangani konflik melalui pendekatan keamanan dan/atau dialog. Meskipun demikian, jika berpijak dari potensi konflik yang masih muncul pasca konflik, di kalangan masyarakat dapat saja masih ada ketidakpuasan pada mekanisme penanganan konflik oleh pemerintah. Negara, melalui pemerintah, terkadang menjadi aktor dalam konflik. Oleh sebab itu, dapat dikatakan wajar jika sebagian masyarakat menganggap keadilan masih jauh dari genggaman mereka.

Munculnya sebuah konflik dikarenakan adanya perbedaan dan keberagaman di Indonesia yang semakin lama menunjukkan adanya konflik dari setiap tindakan-tindakan yang terjadi dan konflik tersebut terbagi secara horizontal dan vertikal. Konflik horizontal adalah konflik yang berkembang di antara anggota kelompok, sepertinya konflik yang berhubungan antara suku, agama, ras, dan antar golongan. Sedangkan konflik vertikal adalah konflik yang terjadi antara masyarakat dan juga negara atau pemerintahan. Umumnya konflik tersebut muncul karena masyarakat tidak puas dengan kinerja pemerintahan.

Di sisi lain, masyarakat Indonesia yang heterogen sebagian masih mengakui eksistensi tradisi atau adat yang bersumber dari nilai-nilai budaya mereka. Pranata adat ini dapat ditelusuri sebagian dari artefak kultural, ada yang pernah difungsikan dalam mekanisme penyelesaian konflik, baik yang berada pada tataran antar individu maupun antar kelompok. Diletakkan dalam konteks Indonesia pasca Soeharto di mana ketidakpercayaan atau ketidakpuasan masyarakat pada mekanisme penyelesaian konflik secara formal, kerap muncul di satu sisi, dan adanya upaya untuk merevitalisasi tradisionalitas termasuk mencakup aspek fungsi lembaga adat (sebagaimana dalam kasuskasus di Kalimantan Tengah. Dengan begitu, tampaklah urgensi pelibatan pranata adat dalam penghentian dan pencegahan konflik Indonesia khususnya di Kalimantan Tengah, kian relevan. Di titik ini, ia merupakan upaya kreatif untuk menghindari atau mencegah terjadinya tumpang tindih penyelesaian konflik melalui mekanisme adat yang tergolong sebagai ADR (Alternative Dispute Resolution) dengan mekanisme formal (misalnya pengadilan) harus dipetakan secara jelas tipologi konflik dan aktoraktor konfliknya.

Menilik pranata adat di Kalimantan Tengah, keberadaan Lembaga Adat Dayak telah diakui sebagaimana tertuang dalam Peraturan Daerah Nomor 16 Tahun 2008 tentang Kelembagaan Adat Dayak di Kalimantan Tengah. Pasal 1 
angka 15 menyebutkan bahwa Adat Istiadat Dayak adalah seperangkat nilai dan norma, kaidah dan keyakinan sosial yang tumbuh dan berkembang bersamaan dengan pertumbuhan dan perkembangan masyarakat adat Dayak serta nilai atau norma lain yang masih dihayati dan dipelihara masyarakat terwujud dalam berbagai pola nilai perilaku kehidupan sosial masyarakat setempat. Selanjutnya pada Pasal 1 angka 18 menyebutkan Kelembagaan Adat Dayak adalah organisasi kemasyarakatan, baik yang sengaja dibentuk maupun yang secara wajar telah tumbuh dan berkembang bersamaan dengan sejarah Masyarakat Adat Dayak dengan wilayah hukum adatnya, serta berhak dan berwenang untuk mengatur, mengurus dan menyelesaikan berbagai permasalahan kehidupan dengan mengacu kepada adat-istiadat, kebiasaankebiasaan dan hukum adat Dayak.

Dari uraian latar belakang di atas, diperoleh suatu permasalahan: pertama, makna dan cakupan pranata adat di Kalimantan Tengah yang juga mencakup aspek sejarah, posisi, peran, fungsi; kedua, bagaimana posisi, peran dan pengaruh pranata adat terutama dalam pencegahan dan penghentian konflik di masyarakat pasca Orde Baru?; ketiga, bagaimana relevansi pranata adat dikaitkan dengan UU Nomor 7 tahun 2012 tentang Penanganan Konflik Sosial dalam kasus konflik antar kelompok masyarakat?

\section{B. Metode Penelitian}

Pendekatan penelitian yang digunakan adalah yuridis sosiologis, artinya suatu penelitian yang dilakukan terhadap keadaan nyata masyarakat atau lingkungan masyarakat dengan maksud dan tujuan untuk menemukan fakta (fact-finding), yang kemudian menuju pada identifikasi (problem-identification) dan pada akhirnya menuju kepada penyelesaian masalah (problem-solution). ${ }^{5}$

Metode yang digunakan adalah etnografi, yang menekankan pada studi aspek budaya. Semula, gagasan budaya terikat dengan persoalan teknis dan lokasi geografis, tetapi sekarang hal itu telah diperluas dengan memasukkan setiap kelompok dalam suatu organisasi, seperti budaya kelompok tertentu.

Teknik pengumpulan data yang digunakan adalah studi dokumen dan field research, yaitu dengan melakukan wawancara pada informan dari institusi pemerintah, termasuk aparatur penegak hukum dan tokoh-tokoh pranata adat dayak. Analisis dilakukan secara kualitatif dan kesimpulan ditarik dengan merujuk pada tujuan penelitian.

\section{Pembahasan}

Berdasarkan data-data yang digali dari informan, maka temuan lapangan yang dapat disimpulkan, yaitu pertama adanya potensi konflik yang ditimbulkan dari kepemilikan tanah, dahulu masyarakat bercocok-tanam dengan berpindah, yaitu setelah penanaman selesai, lalu pindah ke lokasi hutan yang lain untuk penanaman yang baru. Namun pada masa sekarang tidak bisa dilakukan, karena masyarakat yang melakukan tanam berpindah, kemudian kembali ke lahan awal untuk memetik hasilnya tetapi tidak bisa, karena lahan tersebut sudah dipunyai oleh orang lain. Kedua, belum ada mekanisme tanah/lahan yang diambil alih oleh pemerintah. Hal ini tindak lanjut

Soerjono Soekanto, Pengantar Penelitian Hukum, (Jakarta: UI Press, 1982), hlm. 10. 
dari peraturan Pemkot yang menyatakan pada pokoknya, bahwa bila tanah/lahan tidak dikelola selama dua tahun maka menjadi milik pemerintah, tetapi mekanismenya belum diatur. Di samping itu juga, bagaimana pemetaan dan mekanisme yang tepat penyelesaian mengenai tanah adat, hak adat di atas tanah, dan bagaimana dengan tanah ulayat. Ketiga, adanya kekuatan investasi untuk menguasai tanah, hal ini terjadi karena dukungan kuat dari pemilik modal, sehingga berujung pada pihak investor yang dimenangkan, sedangkan masyarakat sebagai pihak yang lemah hanya menerima ganti rugi. Keempat, adanya organisasi/ kelembagaan adat/kemasyarakatan baik yang dibentuk oleh pemerintah, maupun swadaya dinilai kurang memperjuangkan aspirasi masyarakat secara keseluruhan/komprehensif yang bertempat tinggal di Kalimantan Tengah; Kelima, kelembagaan masyarakat adat yang dibentuk oleh Pemerintah Provinsi Kalimantan Tengah, yaitu Dewan Adat Dayak (DAD) Provinsi, di bawahnya DAD Kota, DAD Kabupaten, dan DAD Desa, Mantir di level dusun/kelurahan dan Damang di tingkat desa/kecamatan yang bertugas menangani permasalahan yang berhubungan dengan adat termasuk dalam sengketa tanah adat, anggota dalam struktur organisasinya dari identitas masyarakat budaya Dayak saja. Keenam, masyarakat Dayak sebagai subyek yang mempunyai pola pikir sosial, yaitu bahwa masyarakat yang terampas hakhaknya terutama hak penguasaan tanah yang mengandung nilai ekonomis adalah masyarakat Dayak. Namun, hakekatnya tidak masyarakat Dayak saja, tetapi masyarakat yang terampas haknya juga bisa disebut sebagai masyarakat Dayak, dalam arti yang lain nasibnya sama dengan masyarakat Dayak yang terampas haknya. Hal ini bisa menjadi pemicu konflik yang dilatari identitas budaya/turun-temurun karena mempunyai pikir "permanen" tersebut. Ketujuh, adanya Peraturan Daerah Kalimantan Tengah Nomor 16 Tahun 2008 dan Peraturan Gubernur Kalimantan Tengah Nomor 13 Tahun 2009 yang dinilai masih kurang tepat dalam hal kepemilikan tanah, yaitu Surat Kepemilikan Tanah Adat (SKTA) yang disahkan oleh Damang, sedangkan Surat Kepemilikan Tanah (SKT) yang disahkan oleh Lurah/Kepala, hal ini bisa menyebabkan tumpang tindih dan bagaimana keabsahan surat tersebut; di samping itu, SKTA bisa dimiliki perorangan atau kelompok.

Mengenai pelibatan peran pranata adat yang memakai hukum adat dalam penghentian dan pencegahan konflik masih menjadi solusi yang tepat, seperti konflik antar suku pada tahun 2001 yang mengakibatkan empat orang dayak meninggal, fasilitas umum dan kantor Kepolisian banyak yang dihancurkan, tetapi dengan mengedepankan hukum adat dari pada hukum positif, maka berakhir dengan damai. Kasus lain seperti kasus Ariel - Pieterpan, salah satu Dosen di Universitas Indonesia (UI), yang menyatakan pada esensinya, bahwa "Ariel tidak sepenuhnya salah karena banyak dilakukan oleh orang-orang Dayak di Kalimantan", maka pernyataan tersebut menimbulkan luka bagi masyarakat Kalimantan, akhirnya untuk menebus kesalahan, diselesaikan hukum adat dengan cara membayar denda untuk acara makan bersama dengan orang Dayak Kalimantan Tengah, dan terbukti cara ini manjur untuk mengobati luka masyarakat Dayak Kalimantan Tengah dan tanpa ada dendam.

Paparan di bawah ini akan berupaya menjawab tiga pertanyaan penelitian di atas dengan diawali oleh sekilas konteks sejarah mengenai Kalimantan Tengah dan manusia Dayak Kalimantan Tengah. 


\section{Makna dan Cakupan Pranata Adat di Kalimantan Tengah}

Saat ini yang dimaksudkan dengan adat (kebiasaan setempat atau lokal) dan pranata adat (sistem kebiasaan lokal) di Kalimantan Tengah masih dilihat erat kaitannya dengan pola hidup masyarakat asli atau indigenous people, orang Dayak. Namun demikian perlu juga diingat bahwa konteks masyarakat di Kalimantan Tengah tidaklah hanya didiami oleh orang Dayak saja melainkan telah didiami oleh bergaia migran dari kota-kota lain di Indonesia. Dengan demikian, adat dan pranata adat sudah pasti mengalami perubahan dalam proses yang cukup lama, apalagi yang berkait dengan masalah hukum positif.

Sebelum kita membicarakan masalah adat, pranata adat ada baiknya kita mengetahui dahulu lebih banyak mengenai siapakah orang dayak Kalimantan Tengah itu. Sebelum pulau Kalimantan atau Borneo ini dikenal sebagaimana bentuknya yang sekarang. Pulau Kalimantan terbagi dua untuk wilayah Indonesia dan teritori Malaysia. Wilayah Pulau Kalimantan yang termasuk dalam teritori Indonesia dibagi ke dalam lima provinsi: Kalimantan Barat, Kalimantan Selatan, Kalimantan Tengah, Kalimantan Timur dan Kalimantan Utara. Provinsi Kalimantan Tengah didirikan pada tahun 1957 berdasarkan Undang-Undang Nomor 10 Tahun 1957 dengan Ibukota Palangka Raya. Wilayah ini berlokasi secara strategis di antara dua provinsi lainnya yaitu Kalimantan Barat dan Kalimantan Selatan. Secara topografis, Kalimantan Tengah dikenal sebagai daerah yang kaya akan sumber daya alam berupa hutan tropis, tambang, dan juga lahan gambut. Selama kurun waktu 1800an hingga 1940-an, sebelum Indonesia merdeka Kalimantan Tengah ini merupakan bagian dari teritori kekuasaan administrasi kolonial
Belanda. Kedatangan VOC diawali dengan sebuah ekspedisi di pedalaman (sekarang) Kabupaten Barito dan Kabupaten Kuala Kapuas, sekaligus memperkenalkan mereka dengan ajaran agama Kristen, melalui misi Bassler (Rheiniscische Mission dan Bassler pada 1830s). Hal ini digambarkan oleh sejarahwan Douglas Miles (1976) yang menjelaskan bagaimana orang Dayak berkenalan dengan dunia di luar kosmologi hutan dan sungai-sungai di mana mereka berdiam, dan bagaimaan pengaruh dari luar kemudian perlahan-lahan membentuk pemahaman mengenai identitas Dayak itu sendiri.

Orang Dayak, dengan mendiami wilayah di sekitar hulu sungai dan mempunyai pola bertahan hidup dengan cara ladang berpindah melakukan moda ekonomi tradisional dari masa ke masa. Mereka berdiam di satu tempat dalam membentuk suatu komunitas, kemudian mereka berpindah lagi ke tempat atau hutan yang dianggap masih asri sehingga mampu menopang kebutuhan hidup masyarakat dayak tersebut. Dari sini mulai berkembang atau bertambah banyak komunitas masyarakat dayak yang terbentuk.

MenurutProf. KMAUsop, seorang antropolog alumni Jawaharhal Nehru University/ JNU India yang pernah menjadi Rektor Universitas Palangka Raya, perjumpaan identitas Dayak dengan dentitas di luar dirinya berlangsung sejak masa lampau. Prof. Usop membagi beberapa kategori "integrasi" orang Dayak: integrasi penduduk atau pola pemukiman, integrasi politik, integrasi bahasa, integrasi seni budaya dan integrasi oleh agama-agama.

Dalam konteks integrasi penduduk disebutkan oleh Prof. Usop bahwa faktor migrasi di masa lalu terkait dengan masih menyatunya wilayah Kalimantan-Indonesia dan Kalimantan 
yang menjadi bagian teritori Malaysia. Secara kultural, mereka adalah satu. Penduduk Melayu Tua yang dikenal dengan sebutan Proto Malay/Melayu mendiami wilayah pedalaman, sedangkan Melayu Muda atau Deutero Malay mendiami darerah pesisir atau hilir, sekitar koloni-koloni orang Cina semisal di daerah Banjarmasin sekarang, Pontianak, Kuching dan Kinabalu (Kalimantan bagian Malaysia). Migrasi menyebabkan pembauran di antara Melayu Mdua dan Tua. Orang Dayak adalah bagian dari apa yang disebut sebagai ras Melayu Tua atau Austronesia, dan dengan perkembangannya kemudian, istilah "Dayak" dimaknai sebagai "penduduk pribumi (Kalimantan) yang non muslim. Bernard Sellato antropolog yang meneliti mengenai migrasi orang-orang Dayak dan juga sistem kehidupan mereka menyebutkan juga bahwa faktor perkenalan dengan agama Islam menyebabkan orang dayak keturunan Melayu yang menganut Islam lalu menolak jika dirinya diidentifikasi sebagai Orang Dayak. Dalam perspektif Sellato, migrasi telah sangat mempengaruhi bagaimana orang Dayak mempersepsikan dirinya sendiri di depan perubahan yang terus menerus.

Sementara itu, yang dimaksudkan dengan integrasi politik dalam perspektif Prof. Usop adalah momen di mana orang Dayak menjadi bagian dari pembentukan teritori politik baru pasca kolonia, yaitu di bawah federasi Malaysia, dan empat provinsi di bawah Indonesia. Adapun integrasi bahasa di Kalimantan, yang terbagi menjadi suku-suku berbasiskan aliran sungai telah berkembang sedemikian rupa dan didokumentasikan oleh para ahli bahasa yang melakukan konferensi internasional mengenai bahasa-bahasa. Dengan mengetahui pola pemukiman suku-suku di Kalimantan, terdapat beberapa kelompok dalam penutur bahasa dalam rumpun Austronesia. Di wilayah Kalimantan Tengah khususnya, termasuk daerah Selatan Kabupaten Kotawaringin Barat adalah masuk ke rumpun bahasa Barito atau Ot Danum yang mencakup bahasa Ngaju (di bagian hilir Sungai Barito, Bakumpai, Kahayan, katigan, Sebangau, Mentaya, Pembuang dan Mendawai); daerah orang Dayak Siang dan Murung di hulu Sungai Barito; Lawangan dan Ma'anyan di Barito Tengah. Dalam literatur lainnya mengenai adat Dayak, salah satu referensi mengenai adat adalah yang merujuk pada adat Dayak Ngaju. Dalam perspektif kontemporer tampaknya pola mobilitas orang Dayak Ngaju menjadi faktor di balik penggunaan bahasa Dayak Ngaju sebagai 'lingua franca' di antara suku-suku Dayak di Kalimantan Tengah. Hal ini juga ditegaskan oleh narasumber dalam riset lapangan antara lain Agus Santoso Ketua AMAN Kota Palangkaraya dan Damang di Kahayan Tengah selain Prof. Usop.

Dalam konteks kekinian identitas Dayak masih selalu berkembang dan tidak berhenti atau terisolir dalam ruang dan waktu. Salah satu aspek yang mengalami perbicnangan terus menerus dalam diskursus mengenai orang Dayak adalah kaitan lebensraum mereka di ruang kepercayaan Kaharingan. Dalam penelusuran literatur mengenai identitas Dayak, teramsuk kebudayaan mereka, aspek reliji memang senantiasa menarik. Beberapa referensi penting antara lain Dr. Martin Beier, yang menulis mengenai "Dari Agama Politeis ke Agama Ketuhanan Yang Maha Esa" yang mengulas mengenai teologi sistematika Agama Hindu Kaharingan. Pada tahun 2007 Beier juga pernah mengulas mengenai perkembangan agama baru di Kalimantan Tengah selain aktif pula dalam menulis buku pelajaran Agama Hindu Kaharingan untuk murid SMP kelas III. Dalam 
sudut pandang budayawan JJ Kusni Sulang, "agar bisa meneguhkan eksistensinya sebagai pemeran aktif dalam konstelasi perpolitikan nasional dan daerah maka orang Dayak haruslah mempersiapkan berbagai tawaran. Orang bisa berperan jika ada sesuatu yang "ditawarkan". Salah satu contoh mengenai bagaimana orang Dayak kreatif memperkenalkan diri pada dunia luar dapat dilihat dari tulisan Gubernur Pertama, Tjilik Riwut mengenai "Membangun Alam dan Kebudayaan".

Apa yang ditawarkan oleh Kalimantan Tengah? Selain tentunya, kekayaan alam yaitu kayu dan sumber daya hutan serta tambang yang telah sedemikian banyak dieksploitasi semenjak peraturan mengenai investasi dikeluarkan oleh pemerintah pusat pada tahun 1968. Filosofi adat "rumah betang" yang awalnya mencerminkan aspek komunal hidup bersama orang Dayak di rumah panjang, meskipun tradisi ini telah punah disebabkan oleh masuknya pengaruh modernitas di mana rumah-rumah pribadi dan aspek kekerabatan di antara orang Dayak sendiri telah mengalami pergeseran, masih diasumsikan dapat memberi inspirasi pada hidup berbangsa dan benegara yang intinya harus menjaga suasana damai, tenteram dan sejahtera.

Keinginan untuk mempertahankan adat istiadat Dayak sebagai basis dari budaya lokal mendapatkan respons dari kalangan pemda. Dalam konteks Indonesia pasca Orde Baru, di mana ruang untuk mengekspersikan identitas kultural semakin mendapat tempat, penguatan ekspresi kultural Dayak di Kalimantan Tengah salah satunya diwujudkan dengan terbentuknya lembaga adat Dayak Kalimantan Tengah. Namun ada perbedaan dalam memandang penguatan identitas Dayak ini. Perspektif yang berbeda itu tidak lain adalah bersumber dari kerapnya muncul idiom-idiom "melestarikan budaya lokal", bahkan "pemurnian" dan "mempertahankan" kebudayaan daerah. Secara konseptual, kritik terhadap sudut pandang yang cenderung eksistensialis dalam memandang identitas ke-Dayak-an ini berasal dari argument untuk tidak terjebak dalam kotak-kotak fanatisme kesukuan, namun, hal inilah yang justru tampak ketika pecah konflik Dayak dan Madura di tahun 2001.

Apakah eksistensialisme identitas Dayak ini mencerminkan perjalanan sejarah orang Dayak? Jika kita mencermati penjelasan di bagian awal tulisan ini, jelaslah bahwa orang Dayak telah mengalami periode panjang dari pergumulan identitas dengan budaya-budaya lain. Sebagai misal, kabupaten Pulang Pisau dan Kabupaten Katingan saja telah berlangsung pergeseran komposisi penduduksecara massif. Di Kabupaten Pulang Pisau data WWF menyebutkan dari sisi etnis, 95\% penduduk beretnis Jawa, dan hanya $5 \%$ beretnis Dayak. Sementara itu di Kabupaten Katingan, etnis Dayak sejumlah $45 \%$, etnis Jawa $30 \%$ dan etnis Banjar $10 \%$.

Sementara itu, di konteks pasca Orde Baru, di atas telah disinggung bahwa terjadi instrumentasi terhadap penguatan budaya Dayak melalui formalisasi adat Dayak ke dalam Majelis Adat Dayak Nasional (MADN)-Dewan Adat Dayak (DAD). Upaya ini lalu diformalkan melalui Perda Nomor 16 Tahun 2008. Pada awalnya, inisiatif ini menjadi rekognisi aspek adat untuk mendorong pembangunan manusia, sebab berlangsung dalam ruang di mana orang Dayak tidak melihat dirinya sebagai korban melainkan "survivor". MADN-DAD inilah yang mempunyai otoritas untuk melalukan pelembagaan mulai di tingkat Provinsi hingga Kecamatan, di mana terdapat Damang Adat yang kabtornya terletak di Kecamatan. Damang- 
damang adat ini disandarkan pada Peraturan Daerah Provinsi Kalimantan Tengah Nomor 16 Tahun 2008 tentang Kelembagaan Adat Dayak di Kalimantan Tengah yang diperbarui oleh Peraturan Daerah Provinsi Kalimantan Tengah Nomor 1 Tahun 2010 tentang Perubahan atas Peraturan Daerah Provinsi Kalimantan Tengah Nomor 16/ 2008 tentang Kelembagaan Adat Dayak di Kalimantan Tengah. Peraturan Daerah tersebut juga dikuatkan oleh Peraturan Gubernur Kalimantan Tengah Nomor 13 Tahun 2009 mengenai Tanah adat dan Hak-hak Adat di atas tanah di Provinsi Kalimantan Tengah.

Dari aspek kelengkapan peraturan untuk instrumentasi kelembagaan adat, Peraturan Daerah Provinsi Kalimantan Tengah Nomor 16 Tahun 2008 yang dilengkapi dengan Peraturan Gubernur Kalimantan Tengah Nomor 4 Tahun 2012 tentang Surat Keterangan Tanah Adat (SKT Adat) yang kuasanya berada di tangan Damang adat ini telah cukup lengkap. Peraturan Daerah Provinsi Kalimantan Tengah Nomor 16 Tahun 2008 ini mengatur mulai dari persoalan kelembagaan adat (pembentukan lembaga kedemangan, fungsi, kedudukan tugas damang kepala adat); persoalan mekanisme pembentukan struktur organisasi (pemililihan dan pengangkatan Damang kepala adat, hak memilih dan dipilih); mengenai penyelesaian sengketa adat, dan jenis-jenis sanksi yang dikenakan. Pergub ini juga mengatur mengenai Barisan Pertahanan Masyarakat Adat Dayak, Mantir adat, hak-hak adat dan mengenai pembiayaan. Khususnya dalam hal pembiayaan ini, Bab XXVI Peraturan Daerah Provinsi Kalimantan Tengah Nomor 16 Tahun 2008 menyebutkan bahwa pemda provinsi wajib untuk memberikan bantuan melalui APBD terhada pelaksaaan program kerja Majelis Adat Dayak Provinsi, lembaga Kadamangan, Dewan Adat
Dayak Nasional di Kalimantan Tengah dan Dewa Adat Dayak di Kabupaten/Kota hingga DAD di Desa/Kelurahan. Tampaknya mengintegrasikan instrument adat dalam pemerintahan daerah memang telah menjadi bagian dari komitmen Pemda Provinsi Kalimantan Tengah, terutama jika kita memahami konteks pasca konflik di Kalimantan Tengah.

\section{Posisi, peran dan pengaruh pranata adat terutama dalam pencegahan dan penghentian konflik di masyarakat Kalimantan Tengah pasca Orde Baru.}

Jika kita mendengar mengenai konflik di Kalimantan Tengah asumsi yang umumnya muncul akan merujuk pada periode awal dari proses transisi demokrasi di Indonesia pasca Soeharto di mana terjadi konflik antara Dayak dan Madura di Sampir yang meluas ke beberapa wilayah lain termasuk ibukota Palangkaraya. Dalam wawancara dengan para narasumber di Palangkaraya, disebutkan bahwa di luar konflik etnis yang sifatnya cepat dan menelan banyak korban jiwa itu, Kalimantan Tengah menyimpan bara api yang besar sehubungan dengan over kapitalisasi sumber daya alam oleh perusahaan HPH dan kelapa sawit termasuk juga perusahaan tambang. Provinsi yang didominasi oleh sebelas DAS ini mengandalkan jalur transportasi sungai untuk mengangkut hasil pertanian mereka dengan menggunakan perahu klotok. Di masa lalu ketika belum jaya industri kehutanan, masyakat Dayak sudah terlebih dahulu memanfaatkan hasi-hasil hutan nonkayu dengan cara ladang berpindah dan mencari ikan.

Setelah masuknya industrialisasi sektor kehutanan terutama dengan berlakunya UU PMA dan PMDN tahun 1968, pola ekonomi masyarakat Dayak di pedalaman mengalami 
perubahan. Di satu sisi, UU PMA dan PMDN tersebut mendorong masuknya investor besarbesaran termasuk di pengusahaan hasil hutan kayu dan perkebunan sawit di awal tahun 1970. Faktor lain yang juga turut mendorong terdesaknya orang dayak adalah transmigrasi ke Kalimantan Tengah. Kedua faktor itu, keterdesakan orang Dayak karena industri kayu dan hasil hutan lainnya dikuasai oleh pendatang dan transmigrasi, dianggap sebagai salah satu pemicu kenapa konflik etnis Dayak dan Madura membesar. Ketika konflik etnis itu meledak, Kabupaten Kotawaringin timur (Kotim) telah lama dikenal sebagai daerah penghasil kayu dan karet yang utama. Kabupaten Kotim merupakan daerah penyumbang pembangunan provinsi dari sector hasil hutan berupa kayu, dan selama krisis ekonomi menjelang berakhirnya kekuasaan Presiden Soeharto, menyumbang secara signifikan pada semakin maraknya aktor-aktor lokal di luar perusahaan yang ikut bekerja di sektor pengusahaan hasil hutan ini. Tak pelak,pada konteks ini lalu muncullah istilah "illegal logging" yang dialamatkan pada upaya penebangan kayu di "luar" wilayah yang sidah diberikan konsesi oleh pemerintah. Hal ini dianggap merupakan penyebab marjinalisasi orang Dayak di pedalaman, sebab mereka tidak terbiasa dengan pola pekerjaan di industry perkayuan, terkecuali para migran termasuk dari Madura. Dalam rantai upaya logging atau aktivitas mulai menebang kayu di hutan, mengalirkan balok-balok kayu ke sawmills atau untuk kemudian dipotong dan dijual, orang Dayak cenderung hanya berada pada bagian 'pinggiran".

Pada tahun 2000 setelah reformasi untuk pertama kalinya di Kalimantan Tengah diadakan PemilukadaSung untuk memilih gubernur. Salah satu kandidatnya adalah Prof. KMA usop melalui
PDIP. Menariknya, Prof. Usop kerap kali dituding, bersama lembaganya, LMMDDKT sebagai pihak yang berada di belakang konflik DayakMadura dengan memobilisasi kelompok militan dayak dari pedalaman. Mobilisasi ini ditunjang oleh beredarnya pamflet, seruan-seruan dan berita media massa. Namun demikian, pola penyelesaian konflik di masa konfik etnis itu masih terbatas pada penghentian kekerasan oleh aparat secara langsung (dari beberapa kasus justru menajdi persoalan karena pemihakan aparat pada kelompok yang bertikai). Namun dalam suatu wawancara dengan Prof. Usop di tahun 2004, beliau menyebutkan bahwa dia tidak mempunyai kapasitas untuk memobilisasi massa. Orang-orang Dayak yang datang dari pedalaman semata-mata menuntut "bela" saudara mereka. Apa yang dibenci dari orang Madura adalah kecenderungan mereka untuk mengambil semena-mena apa yang sebenanrnya menjadi "hak kultural" orang Dayak. Salah satu manifestasi kontemporer dari perlindungan terhadap hak orang Dayak ini adalah diterbitkannya SKT Adat yang mengatur kepemilikan hak atas tanah adat Dayak ini. Jadi, memahami kompleksitas permasalahan yang melatarbelakangi konflik dan merefleksikannya dengan apa yang berlangsung dengan penguatan identitas dan pembentukan kelembagaan adat Dayak dengan tujuan utama untuk menjamin perlindungan terhadap identitas dan hak-hak kultural mereka melalui Peraturan Daerah Provinsi Kalimantan Tengah Nomor 16 Tahun 2008 serta Peraturan Gubernur Kalimantan Tengah Nomor 4 Tahun 2012 tentang SKT Adat, menjadi masuk akal. Di masa pasca konflik etnis, aspek ketimpangan ekonomi karena investasi di sektor sumberdaya alam, migrasi, penyeragaman struktur pemerintahan daerah yang menyingkirkan aspek lembaga tradisional 
melalui Undang-Undang Nomor 5 Tahun 1974 disebut sebagai faktor-faktor yang turut mendukung berkembangnya kegetiran orang Dayak yang dituangkan dalam bentuk kekerasan antar etnis; di samping penjelasan mengenai prasangka kultural.

Pasca konflik etnis tersebut, pemda Kabupaten Kotawaringin Timur mengeluarkan peraturan mengenai kependudukan yang ditujukan untuk mengatur penduduk non permanen. Lalu diatur dalam Peraturan Daerah Provinsi tahun 2003. Persoalan rekonsiliasi di akar rumput pasca konflik, dengan mengutip keterangan professor KMA Usop dan Sekjen DAD, Siun Jarias, diselesaikan dengan cara natural atau alamiah. Beberapa upaya untuk mencapai perdamaian pasca konflik juga tercatat berlangsng di antara tahun 20022003. Pada tahun 2002, pemda Provinsi melalui Peraturan Gubernur Kalimantan Tengah Nomor 343 Tahun 2002 mengeluarkan "komite kerja untuk menangani konflik etnis" yang strukturnya tersebar mulai provinsi hingga kecamatan.

Aktivasi pranata adat di Kalimantan Tengah saat ini dicakup dalam Peraturan Daerah Provinsi Kalimantan Tengah Nomor 16 Tahun 2008 khususnya Bab X (pasal 27-32) tentang penyelesaian Sengketa; dan Bab XI tentang Jenis Sanksi. Sengketa yang dimaksudkan dalam hal ini berkaitan dengan sengketa adat, di mana dapat diajukan pada Kerapatan Mantir (pembantu Damang adat) yang terletak di wilayah Desa/ Kelurahan maupun Kecamatan. Pengaduan terhadap kasus adat ini juga mencakup aspek yang terkait dengan perselisihan di wilayah rumah tangga (misalnya perselingkuhan) yang harus diselesaikan dengan membayar denda adat ("singer") atau bentul-bentuk sanksi adat lainnya. Selain itu, mekanisme penyelesaian sengketa ini juga berpijak pada metode musyawarah adat. Dengan model penyelesaian konflik yang berjenjang, suatu masalah yang tidak dapat diselesaikan di tingkat Kerapatan Mantir/Let Perdamaian Adat di Desa atau Kelurahan makan akan dibawa untuk diselesaikan di tingkat Kerapatan mantir/ Let Perdamaian Adat tingkat Kecamatan.

Sanksi yang diberikan pun dijatuhkan setelah melalui pengambilan keputusan Kerapatan Mantir/Let Perdamaian Adat di tingkat kecamatand an sifatnya mengikat. Ada pula mekanisme Sumpah Adat yang diberlakukan jika ada suatu kasus yang sulit untuk dibuktikan. Dalam suatu kasus, maka pemberian keputusan adat pada pihak yang bersengketa akan menjadi pertimbangan bagi aparat hukum yang memang terlibat dalam penyelesaian perkara. Barangkali perlu ditelusuri sejauh mana aspek pemberian sanksi adat atau keputusan untuk menyelesaikan perkara secara adat ini akan overlap dengan mekanisme pemberian hukum dari ranah hukum positif. Tampaknya ke depan, perlu diikuti bagaimana pelaksanaan Pergub Kalimantan Tengah mengenai SKT yang tidak berpotensi konflik dengan aspek legal kepemilikan tanah lainnya. Hal ini disebabkan bahwa klaim terhadap SKT Adat telah cenderung berpotensi konflik karena suatu individu atau kelompok atas nama adat Dayak dapat mengklaim kepemilikan tanah tertentu Sementara ini, konteks pembangunan daerah yang sarat dengan investasi untuk perkebunan sawit juga telah menuai pertikaian antara orang Dayak versus perusahaan sawit. Di sisi lain, ada kecenderungan bahwa meningkatnya klaim akan tanah adat juga mendesak kepemilikan tanah dari migran atau orang non Dayak di perkotaan (Palangkaraya). 
3. Relevansi pranata adat dikaitkan dengan Undang-Undang Nomor 7 Tahun 2012 tentang Penanganan Konflik Sosial dalam Kasus Konflik Sosial

Secara ideal, dengan adanya Peraturan Daerah Provinsi Kalimantan Tengah Nomor 16 Tahun 2008 dan Peraturan Daerah Provinsi Kalimantan Tengah Nomor 7 Tahun 2012 maka ke depan dapat diarahkan suatu kebijakan yang tidak tumpang tindih bahkan dapat terintegrasi. Setidaknya jika kita menggunakan perspektif "pencegahan konflik" maka substansi penyelesaian sengketa adat yang dimaksudkan tertuang dalam Peraturan Daerah Provinsi Kalimantan Tengah Nomor 16 Tahun 2008 dapat menjadi instrumen untuk itu. Selain itu, ketika mensinkronkan antara relevansi pranata adat yang tertuang dalam Peraturan Daerah Provinsi Kalimantan Tengah Nomor 16 Tahun 2008 dengan Undang-Undang Nomor 7 Tahun 2012, dapat dipetakan bahwa dalam suatu konteks masyarakat yang heterogen terdapat triangulasi untuk aktor-aktor yang terlibat dalam resolusi konflik sebagai berikut:

Diagram 1. Aktor-aktor Resolusi Konflik (secara umum maupun di Kalimantan Tengah)

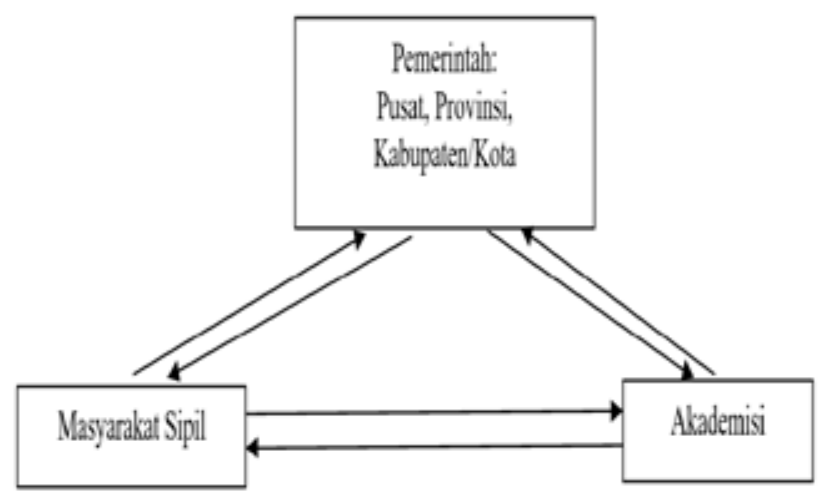

Pada dasarnya, dalam Peraturan Gubernur Kalimantan Tengah Nomor 16 Tahun 2008 ketiga kelompok aktoryang ada di dalam diagram di atas telah terlibat pada aspek konseptual maupun praktik penyelesaian konflik di Kalimantan Tengah. Khususnya pada konteks reformasi pasca Order baru, Masyarakat Sipil (termasuk kelompok adat) telah banyak mengambil peran melalui agenda workshop, fasilitasi dialog, dan dalam konteks Kalimantan Tengah.

Aktor Pemerintah diantaranya: KPP PA, Kementerian Hukum dan HAM, Kementerian Dalam Negeri, Kementerian Kehutanan dan Lingkungan Hidup, Kementerian Pendidikan dan Kebudayaan, Kementerian Agama, Kementerian Kesehatan, Kementerian Keuangan, BAPPENAS, BNPB, Kemenkopolhukam, Kementerian Pertahanan, POLRI Kejaksaan, BPS, Kementerian Pertanian, Kementerian Agraria dan Tata Ruang/BPN, Kementerian Ketenagakerjaan, Kementerian Transmigrasi dan Desa Tertinggal, Kementerian ESDM, Mahkamah Agung, BIN.

Aktor Pemerintah Provinsi (pada umumnya, bisa juga diaplikasikan di Kalimantan Tengah), diantaranya: Biro/Badan/Kantor Pemberdayaan Perempuan, Bappeda Provinsi, Kanwil Kementerian Hukum dan HAM, Bakesbangpolinmas, Dinas Pendidikan dan Kebudayaan, Dinas Kesehatan, Dinas Pertanian, Dinas Kehutanan, Dinas Transmigrasi dan Pertambangan, BPBD, Kanwil Agraria/BPN, Kanwil Agama, Kanwil Keuangan, Pengadilan Tinggi, Kepolisian Daerah, Kejaksaan Tinggi. Sedangkan aktor di Pemerintah Kabupaten/Kota diantaranya: Biro/Kantor/Badan Pemberdayaan Perempuan, Bappeda, BPBD, Polres, Kejaksaan Negeri, Pengadilan Negeri, Unit Pelaksanan Teknis, Dinas-Dinas yang ada di Kabupaten/ Kota.

Peran pemerintah dalam Pencegahan Konflik adalah harmonisasi produk hukum di daerah dengan peraturan lebih tinggi yang rights-based 
approached; melakukan peningkatan kapasitas aparat pemerintah, aparat keamanan, aparat penegak hukum; memanfaatkan institusi yang sudah eksis sebelumnya seperti religious-based organizations atau organisasi etnik, profesi, dan sebagainya.

Dalam Undang-Undang Nomor 7 Tahun 2012 tentang Penanganan Konflik Sosial tersebut, ada beberapa pokok persoalan yang dapat dijabarkan sebagai berikut:

1. Tujuan Undang-Undang:

a. memberikan perlindungan dan pemenuhan hak korban, memulihkan kondisi fisik dan mental masyarakat termasuk perempuan dan anak.

b. UU tersebut mempertegas tanggung jawab pemerintah dan pemerintah daerah untuk:

1) Melakukan tindakan darurat penyelamatan dan perlindungan korban yang meliputi diantaranya:

a) pemenuhan kebutuhan dasar pengungsi, termasuk kebutuhan spesifik perempuan dan anakanak ( Pasal 32 ayat (2) huruf c).

b) memberikan pelindungan terhadap kelompok rentan (Pasal 32 ayat (2) huruf d).

2) Melakukan rehabilitasi diantaranya dengan:

a) Pemulihan psikologis korban konflik dan pelindungan kelompok rentan (Pasal 38 ayat (2) huruf a).

b) Pemenuhan kebutuhan dasar spesifik perempuan dan anak (Pasal 38 ayat (2) huruf g).

c) Pemenuhan kebutuhan dan pelayanan kesehatan reproduksi bagi kelompok perempuan (Pasal 38 ayat (2) huruf $h$ ). d) Peningkatan pelayanan kesehatan anak-anak ( Pasal 38 ayat (2) huruf 1).

3) Melakukan rekonstruksi, diantaranya melakukan perbaikan dan penyediaan fasilitasi pelayanan pemenuhan kebutuhan dasar spesifik perempuan dan anak anak (Pasal 39 ayat (2) huruf e).

2. Sensitif gender.

3. Multi stakeholder dalam pelaksanaannya sampai dengan pemerintah daerah.

4. Costly-masalah Kelembagaan: Pembentukan Satgas Konflik Sosial - politik.

5. Definisi yang problematik: konflik sosial, yang selanjutnya disebut konflik, adalah perseteruan dan/atau benturan fisik dengan kekerasan antara dua kelompok masyarakat atau lebih yang berlangsung dalam waktu tertentu dan berdampak luas yang mengakibatkan ketidakamanan dan disintegrasi sosial sehingga mengganggu stabilitas nasional dan menghambat pembangunan nasional.

Berbagai upaya untuk menjaga stabilitas keamanan yang telah dilakukan oleh pranata adat di Kalimantan Tengah, adalah untuk mewujudkan keadilan dan kedamaian. Karena dengan kedamaian bangsa kita dapat melanjutkan pembangunan yang dapat dirasakan oleh masyarakat secara adil, selain itu dengan kedamaian bangsa Indonesia dapat mengisi kemerdekaan sebagaimana yang telah dicita-citakan oleh para pahlawan. Eksistensi Pranata Adat Dayak merupakan pencerminan upaya masyarakat dayak dalam menggali, melestarikan dan mengembangkan budaya adat melalui penerapan adat istiadat dan hukum adat pada kehidupan masyarakat. Pemerintah 
juga memandang penting pengembangan adat istiadat ini, karena dengan masih terpeliharanya adat istiadat, berarti masyarakat masih menjunjung tinggi hukum adat yang ada di Indonesia. Karena hukum adat inilah satusatunya hukum atau norma yang dimiliki oleh masyarakat Indonesia sejak dari dahulu kala. Presiden Soeharto pernah mengemukanan bahwa "Bangsa yang lupa budayanya akan kehilangan kepribadiannya, bangsa yang kehilangan kepribadiannya menjadi bangsa yang lemah, bangsa yang lemah akan runtuh dari luar dan hancur dari dalam."

Atas dasar itu bangsa Indonesia harus berusaha terus menerus memelihara semua warisan budaya dan adat istiadat. Sekali saja suatu generasi melupakan budayanya sendiri, maka warisan budaya itu akan lenyap. Adat istiadat dan Hukum Adat Dayak di Kalimantan Tengah sejak dahulu telah tumbuh dan berkembang serta dipatuhi oleh masyarakat adat. Meskipun demikian, pemberlakuan Hukum Adat di Kalimantan Tengah tetap dengan tidak mengesampingkan Hukum Nasional.

\section{Penutup}

Dari hasil pembahasan dapat disimpulkan beberapa hal sebagai berikut: pranata adat sangat berpengaruh dan pengaruhnya tidak hanya pada peran saja tetapi juga ada legalitas mengenai kewenangan kelembagaan adat yang dibentuk oleh pemerintah daerah dalam penyelesaian konflik terutama pada level yang menyangkut masyarakat.

Adanya Peraturan Daerah Provinsi Kalimantan Tengah Nomor 16 Tahun 2008 dan Undang-Undang Penaganan Konflik Sosial Nomor 7 Tahun 2012 yang dipandang masih tumpang tindih, maka ke depan dapat diarahkan suatu kebijakan yang tidak tumpang tindih bahkan dapat terintegrasi. Setidaknya jika kita menggunakan perspektif "pencegahan konflik" maka substansi penyelesaian sengketa adat yang dimaksudkan tertuang dalam Peraturan Daerah Provinsi Kalimantan Tengah Nomor 16 Tahun 2008 dapat menjadi instrumen untuk pencegahan dan penghentian konflik antar kelompok masyarakat.

Atas dasar hal tersebut disarankan kepada Pemerintah daerah harus melibatkan pranata adat dan tokoh adat setempat dalam penanganan konflik soaial yang terjadi di daerahnya. Dan bagi Pemerintah Pusat dalam hal ini Direktorat Jenderal Peraturan PerundangUndangan perlu menerbitkan Peraturan Pemerintah Pelaksanaan Undang-Undang Nomor 7 Tahun 2012 tentang Penanganan Konflik Sosial yang di dalamnya memuat secara komprehensif pelibatan pranata adat dan tokoh adat dalam penanganan konflik sosial.

\section{Daftar Pustaka}

\section{Buku}

Anderson, Benedict, Imagined Communites: Reflecitions on the Origin and Spread of nationalism, (London: Verso, 1983)

Cahyono, Heru ed., Konflik Elite Politik di Pedesaan: Relasi Antara BPD dengan Pemerintah Desa, (Jakarta: P2P LIPI, 2004)

Geertz, Clifford, Available Light: Anthropological Reflections on Philosophical Topics (New Jersey: Princeton University Press, 2000)

McVey, Ruth, (ed), "Indonesia", (Cornell, 1967)

Lane, Max, Bangsa Yang belum Selesai: Indonesia Sebelum dan Sesudah Soeharto, (Jakarta: Reform Institute, 2007)

Sulang, JJ kusni, Negara Etnik, Beberapa gagasan Pemberdayaan Suku Dayak, (Yogyakarta: Fuspad, 2001)

Fisher, Simon, dkk., Mengelola Konflik Keterampilan dan Strategi Untuk Bertindak, (Jakarta: British Counsil, Indonesia, 2001)

Soekanto, Soerjono, Pengantar Penelitian Hukum, (Jakarta: UI Press, 1982) 
Wirawan, Konflik dan Manajemen Konflik, Teori, Aplikasi dan Penelitian, (Jakarta: Humanika, 2010)

Makalah/Artikel/Laporan/Hasil Penelitian

Magenda, Burhan D., "Perubahan dan Kesinambungan dalam Pembelahan Masyarakat Indonesia", Prisma, 4, (1990)

Pabottinggi, Mochtar, "Lima Palang Demokrasi, Satu Solusi" (Orasi Ilmiah Pengukuhan sebagai Ahli Peneliti Utama, Jakarta, PPW-LIPI, 22 Juni 2000)

\section{Peraturan}

Undang-Undang Nomor 32 Tahun 2004 tentang Pemerintahan Daerah;

Undang-Undang Nomor 7 Tahun 2012 tentang Penanganan Konflik Sosial;

Peraturan Daerah Provinsi Kalimantan Tengah Nomor 16 Tahun 2008 tentang Kelembagaan Adat Dayak di Kalimantan Tengah

Peraturan Gubernur Kalimantan Tengah Nomor 4 Tahun 2012 tentang Surat Keterangan Tanah Adat 